\title{
E3 SUMO-Protein Ligase CBX4
}

National Cancer Institute

\section{Source}

National Cancer Institute. E3 SUMO-Protein Ligase CBX4. NCI Thesaurus. Code C73684.

E3 SUMO-protein lig ase CBX4 (558 aa, $\sim 61 \mathrm{kDa}$ ) is encoded by the human CBX4 gene.

This soluble, nuclear protein plays a role in repressing the expression of genes through

SUMOylation of lysine 119 of histone H2A. 